\title{
Struggle with School Absenteeism in Compulsory Education: Different Country Approaches and Policies
}

\author{
Sait Akbaşıı ${ }^{1}$, Mehmet Şahin ${ }^{2, *}$, St. Pınar Mardin Yılmaz ${ }^{3}$ \\ ${ }^{1}$ Faculty of Education, Hacettepe University, Turkey \\ ${ }^{2}$ Ahmet Keleşoğlu Faculty of Education, Necmettin Erbakan University, Turkey \\ ${ }^{3}$ Educational Science Institute, Hacettepe University, Turkey
}

Copyright $\mathrm{O} 2017$ by authors, all rights reserved. Authors agree that this article remains permanently open access under the terms of the Creative Commons Attribution License 4.0 International License

\begin{abstract}
This research has been conducted to discuss the absenteeism in compulsory education and the proposed policies for reducing this problem with the school practices. In this context, the general situation regarding the absenteeism in the Turkish education system has been put forward and the current practices and policies have been addressed. Furthermore, in other countries, the current situation and practices of non-attendance in the compulsory education process and what can be done are discussed. This research is a qualitative research and case study designed. In the research, data were collected via literature research. During the collection of data; in addition to the literature on absenteeism in our country, it has been also benefited from the publications of the education ministries of the countries and other academic documents in order to see how is address internationally. In this context, the approaches and strategies that are generally followed by countries are investigated by looking at the absenteeism processes of the countries. In particular, referring to example approaches and policies incentives and support mechanisms are described. In this context, the main approaches are; legal regulations, in-school practices, computer technology and family-supported practices.
\end{abstract}

Keywords Absenteeism, Causes of Absenteeism, Encouragement

\section{Introduction}

In generally, it is defined as absenteeism from school without any valid excuses (Stoll, 1990). From the literature view, there are several definitions of absenteeism that they do not make much difference. Absenteeism is also referred to as the absence of schooling, with or without a valid reason (Kearney, 2008). According to Altınkurt (2008), absenteeism is defined as a behavior of a student who may be dependent or external to himself / herself and is thought to negatively affect the academic success of the student. According to Turkey Ministry of Education (MoNE) 2015-2019 Strategic Plan, absenteeism is defined as the absence of schooling, with or without a valid reason (MoNE, 2015a).

Absenteeism and truancy are are used interchangeably. But in fact they have different meanings. Truancy is used when students deliberately stay away from school without permission. Truancy is known amongst other things as 'skipping off', 'mitching', 'dodging', 'skiving', 'bunking-off' and 'going missing' (Reid, 2000). On the other hand absenteeism is a more general concept that means regular absence from work or school without a good reason. In this study, the expression of absenteeism is defined in this way.

There are various reasons for student absenteeism. In general, multiple factors play a role in the emergence and maintenance of absenteeism. These factors are; the lack of community support, school environment, the presence of various problems in family life, the inconvenience of school transportation, the emergence of health problems, bad weather and individual factors (Teasley, 2004). Despite similar results in the general research on student absences, there are some changes depending on factors such as culture, education level, legal requirements. Shute and Cooper (2015) point out that family and home environment, student and school give rise to school absenteeism. Similar results were obtained in the research conducted by Öztekin (2013) and the reasons of absenteeism were handled in seven dimensions as student-originated, family-based, teacher-originated, school and school-based, health-related, friend-environment and environment-based. In accordance with researches, in generaally, the causes are generally grouped in seven groups as social factors, economic factors, family factors, environmental factors, psychological factors, school-based factors and personal factors (Reid, 2014).

In addition to academic success, students who have problems with absenteeism face many problems. When the absenteeism becomes a habit, it also brings out the consequences of going out of formal education or early 
school leaving. And also, in the long term, it may leads to inability to find work, loneliness and social problems (Rivers, 2010). Moreover, it is known that there is a positive relationship between absence and harmful habits, crime processing and violence (Henry, 2007).

Absenteeism can negatively affect sustainable development. Especially in our country which has a young population, the problems associated with absenteeism are felt more clearly. For this reason, the process about school attendance is a problem that needs to be resolved in Turkey. It is thought that the researches aiming to produce solutions for the problem of student absenteeism can contribute indirectly to the social development and development as well as the direct contributions to the education system in the first place. However, when researches on the subject at the national level are examined, it is seen that the studies are mostly focused on the reasons for absenteeism (Education Reform Initiative, 2015; Özbaş, 2010). For this reason, the approaches and practices that have been considered in reducing the absence of absenteeism in the research rather than the causes of absenteeism. Along with the process in Turkey, different approaches and policies of different countries have been mentioned. For all these reasons, in the research, it has been aimed to research different struggle methods and strategies that applied to school absenteeism for compulsory education in Turkey and other countries. In line with the general objective, the following questions are tried to be solved.

(1) What is the current legislation for absenteeism in Turkey?

(2) What is the current legislation for absenteeism in different countries?

(3) What are the approaches and policies about absenteeism in different countries?

(4) What are the suggestions for struggle with school absenteeism?

\section{Method}

The study aims to present the present situation in Turkey and in some other countries in a comparative way based on legislative documents and regulations. The study was carried out using qualitative research method in accordance with case study design. Qualitative research method, aiming to make an in-depth examination of a phenomenon within its own reality, was considered more appropriate for the present study. Situations are limited to time and action, and researchers collect detailed information using a variety of data collection methods over a long period of time (Creswell, 2014; Büyüköztürk ve diğ., 2013). Literature research was used as data collection tool.

\section{Situation of Countries for Compulsory Education}

Compulsory education means that all individuals who have entered the age of education in a country are subjected to the process of being in a similar schooling with the content and duration of legal arrangements. In conclusion, it means legally-required period of time that children are expected to attend school.

Nowadays, almost all modern education systems are regulated by national law legislation; and it has compulsory education changing with time and scope. Thanks to compulsory education, every individual in the society is equipped with the knowledge and skills that are thought to be necessary for adapting to the structure of modern society; the rules of behavior that must be complied with. And also individuals learn the rules of behavior, rights, duties and responsibilities that must be followed (Akçabay, 2012).

In Turkey, with "the Primary Education and Training Law no 6287" adopted on March 30, 2012 also called as 4+4+4 system, compulsory education was increased to 12 years, and the secondary education was taken into the scope of compulsory education. Within the scope of this reform, the duration of compulsory education, the names and the duration of the school grades have been changed, the transition between grades has been arranged, new elective courses have been set up. However, as in many countries, in Turkey, there are many students who cannot attend regular training for various reasons during when schools are open to education (Önder, 2017).

According to UNESCO data, compulsory education periods vary between 4 and 13 years. The duration of compulsory education is between 4-6 years in 51 of the 192 countries, 7-9 years in 86 countries, and 10-13 years in 59 countries. There is one country where the duration of compulsory education 4 years and there are 10 countries where it lasts 5 years. In this context, the shortest times (average 6 years) are seen in African and Asian countries, the longest times (10 years and over), North America, Europe and Central Asia. On the other hand, when age limits (starting and leaving ages) associated with compulsory education are examined, it is observed that the age limits on the global scale vary between 4 and 18 years (Eurydice, 2015; MoNE, 2015b).

The length of compulsory education in the United States differs from state to state. Compulsory education in general, together with the difference, includes the education of children in the 6-16 age group. Considering the applications for the duration of compulsory education, There are four alternatives in the form of $6+6 ; 6+3+3 ; 4+4+4 ; 8+4$ (Demirtas, 2011).

\section{Strategies for Struggle with School Absenteeism}

There are a variety of strategies and practices to struggle with school absenteeism. It may not be right to intervene at a point as there is no single cause of absenteeism. In general, the development of a national absenteeism intervention tool, 
the development of an early warning system, the arrangement of educational environments according to the needs of the students, the implementation of deterrent sanctions and the development of school-family relations are the regulations works that can be done to struggle with school absenteeism (Ahmad ve Miller, 2015).

In the 2015-2018 Strategic Plan, the Ministry of National Education outlined the concept of absenteeism and set various strategies for this issue. When the plan is considered, $34.8 \%$ of student had absenteeism over 20 days in 2014 . It is seen that the rate of $25.3 \%$ in primary and secondary schools aims to decrease to $10 \%$ and in secondary education it is $38.9 \%$ to $20 \%$ (MEB, 2015). In addition, the following strategies have been identified on the plan.

- Investigations will be conducted to determine the reasons for absenteeism, grade repetition and early school leaving in all school types and grades.

- "Secondary Education Orientation Program" will be generalized in order to reduce absenteeism, class repetition and school dropout in secondary education.

- Mechanisms for monitoring and preventing student absenteeism will be developed to prevent early school leaving from compulsory education and to reduce school absenteeism.

The Ministry of National Education is carrying out various projects and studies to reduce the increasing absenteeism rates. The Directorate General for Basic Education has done a project on increasing the Attendance Rates to Primary Education Institutions in order to increase the attendance rates in primary education including the first eight years of twelve years of compulsory education. Project was carried out between October 2013 and October 2015 and the activities were in a total of 120 pilot schools in 12 provinces (Agri, Van, Mus, Diyarbakir, Bitlis, Bingöl, Batman, Şanlıurfa, Şırnak, Hakkari, Mardin, Siirt).

The General Directorate of Secondary Education have done the project on the Development and Implementation of the Intervention Model to prevent interventions for students at risk of dropping out of school at secondary level and to ensure that those who had left school were able to acquire some skills by being brought to school outside of class hours. Within the scope of the project, a training program was prepared and put into practice. It is also important to prevent absenteeism in the project.

One of the objectives of the Secondary Education Orientation Project conducted by the General Directorate of Secondary Education on the average of the number of days absent from the 9th grade in Turkey is to lower the absenteeism rates. The Secondary Education Orientation Program prepared for this purpose has been implemented in the pilot provinces and it has been decided to spread it after successful results have been obtained. It is expected that the secondary school adjustment program will be generalized to all schools at the secondary level.

General Directorate of Vocational and Technical Education have done the projects named School Attendance
Rates Especially for Girls (KEP-1) and KEP-2 in order to increase school attendance rates at primary and secondary school levels, to increase their professional skills and competencies, and to raise awareness among parents about the importance of education for their families. And also initiated a study to investigate the causes of the absenteeism, grade repetition and drop out.

From the point of view of different country practices, it is seen that different strategies have been applied in struggle with school absenteeism. For example, since 1986 in the United States, the National Center for School Engagement has been conducting researches. In the context of the studies, the task of reducing the school dropout rate of the United States is carried out on the students who are at risk inclusive disabled students. In this context, the use of some effective strategies has come to the forefront. These strategies are generally divided into four categories: School and community-based practices, early interventions, core strategies and benefit from education mostly (Smink ve Reimer, 2005).

The policy document issued by the Australian Queensland Government Education Department also highlighted the five main strategies that could be carried out for students to attend the school. These are; create a positive school culture, communicate high expectations of attendance (school website, newsletters and registration package), record and follow up various statistics (Queensland Government Education Department, Training and Employment, 2015).

In the studies conducted by Hanover Research (2016), research-based strategies for absenteeism at secondary and high school levels and three school districts that were successful in improving their participation were investigated. In this context, the strategies are forward:

- Understanding the causes and effects of absenteeism has crucial importance in the design of strategies and programs that target the attendance of students.

- A collaborative approach is required.

- Individual support strategies, including counseling and graduation coaches, can help encourage attendance schooling and participation.

- Smaller learning communities offer a more flexible, personalized and responsive environment that contributes to increased student participation and academic success.

- Impressive and meaningful instruction also encourages students to continue at secondary school level.

Strategies for absenteeism are also mentioned in a document issued by the Australian Ministry of Education. The main strategies for documenting the situation, information, monitoring, rewards / incentives and other elements are mentioned. Rewards and incentives are (Victoria State Government Education and Training Department, 2017):

- $\quad$ Providing a term award, for example a sausage sizzle or extra sports activity, for all students who have attended every day. 
- Presenting weekly 'class on-time' awards at assembly.

- $\quad$ Providing a special excursion once a year for the top 20 per cent of attendees for the year.

- Introducing attendance prizes each term, for example basketballs, footballs and tennis racquets, for 100 per cent attendance for the term and a smaller prize (cinema ticket) for 90 per cent or greater attendance.

- Issuing raffle tickets to students with good attendance. At the end of each week, the raffle for a showbag is drawn.

- Organizing a friendly competition between rooms or sections of the school based on attendance for the term, for example having a free BBQ sausage sizzle lunch for the 'winning' group.

- Introducing attendance prizes each month (certificates and some fun stationery) that are awarded for full attendance.

- Sending reminders to students at the end of each school day about the exciting things they can expect to happen at school the following day.

The policy document issued by the Government of Wales also includes suggestions and practices on student attendance. In this context, the use of prizes and incentives to encourage participation and punctuality has been mentioned. It is also emphasized that the awards have a more motivating role than punishment (Welsh Government, 2011).

A three-tiered structure for attendance and participation has been adopted, and appropriate strategies have been indicated, with a published report on British school districts in Priority Early Outreach for Positive Linkages and Engagement (PEOPLE) (Vaverchak, J. and Harris, S., 2014). That means;

- Priority: Focuses on at-risk students in grades, schools and neighborhoods with high levels of chronic absence

- Early: Begins with the start of school.

- Outreach: Connects to students and families

- Positive: Promotes preventive, supportive approaches rather than punitive responses

- Linkages: Taps the full community for support

- Engagement: Motivates showing up to class \& offers students \& families a role in improving attendance.

- Figure 1 shows that people helps ensure adoption on a tiered approach that begins with prevention.

Along with the policies and approaches carried out in Turkey and other countries, it is understood that absenteeism struggle programs is generally considered in four groups in the literature (Gullatt ve LeMoine, 1997). The first group consists of legal regulations used to prevent absenteeism by public and state entrepreneurs. The second group includes in-school practices used by school administrators. The third group focuses on the use of computer technology to combat absenteeism. The fourth group consists of family support programs.

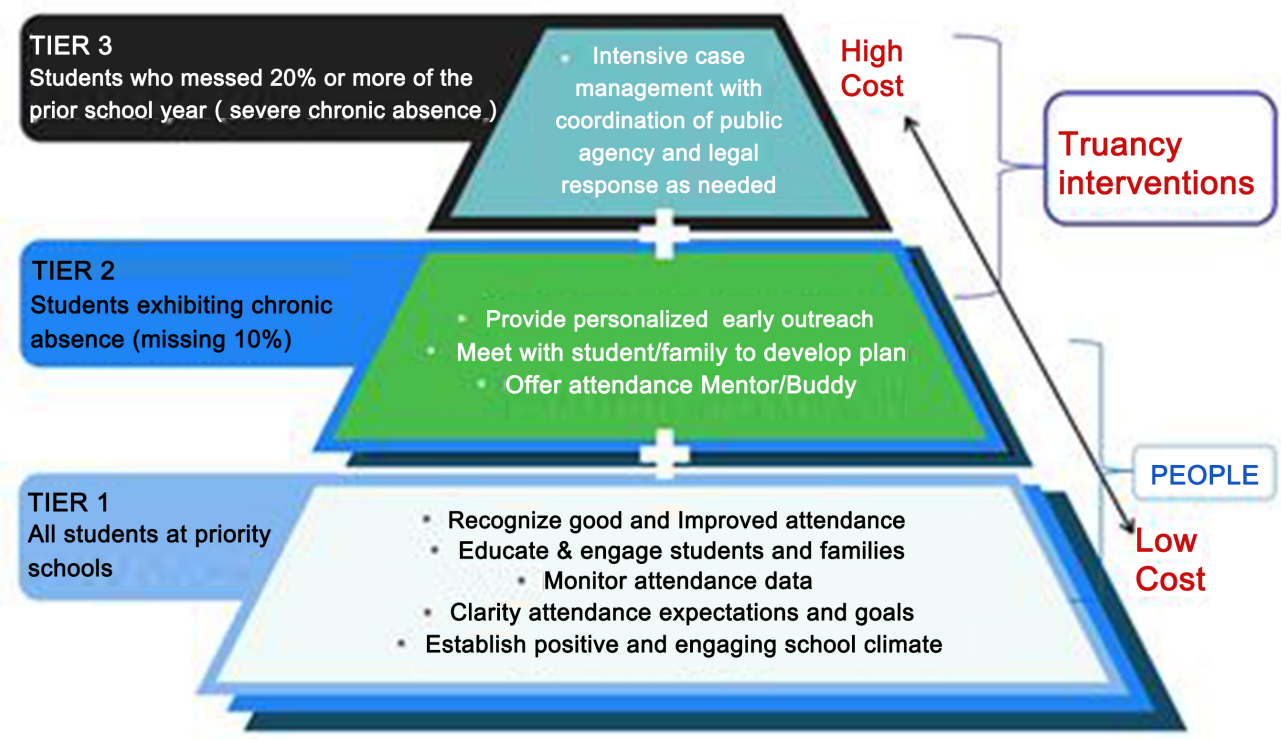

Figure 1. Three-tiered structure about attendance school in the UK 


\subsection{Legal Regulations}

In Turkey with the Law No. 4306 in 1997, eight year uninterrupted compulsory primary education was introduced. Compulsory education has been increased to the 12th year with the "Law on Primary Education and Education No. 6287" which is also referred to as the $4+4+4$ system accepted on March 30, 2012 and secondary education has been included in compulsory education.

According to the regulation of the Ministry of National Education (MoNE) Preschool Education and Primary Education Institutions, grade repetition is not used for primary school students. In relation to absenteeism, "the child who has not continued schooling for 10 days without any valid reason" is warned with the letter by the school director. Despite this warning, the register isdeleted for children who do not continue school for 30 days. In the middle school, the border situation regarding absenteeism is stated as 20 days without excuse.

According to the Basic Law of National Education, secondary education is obligatory. The absenteeism limit that students can make during the course of the year and the methods to be applied when they do not comply with this period are determined by the Ministry of National Education Regulation for Secondary Education Institutions. According to the Regulation, students who exceed 10 days with excuse and total 30 days without any valid will be considered unsuccessful regardless of their course scores. But this period is 60 days with the health report (MoNE, 2013).

The number of absences of the student (with excuse or without excuse) is a valid reason for grade repetition in some countries including Italy, Cyprus, Hungary, Poland, Portugal and Romania. In each of these countries, the limit on the number of absences has been determined. If this number is exceeded, student can't be succesful to go to next grade.

In Italy, if a participation rate is less than $75 \%$ during the entire training period, the student may need to repeat the class. In Cyprus, a student can take a class offense if there is no valid reason 51 or if there is a 161 absenteeism regardless of whether there is a valid reason. In Hungary, it is not possible for a teacher to assess a student at the end of a school year if the total number of absences of the pupil in a school year exceeds 250 class hours, or if the student misses more than $30 \%$ of lessons. In Portugal, the total annual amount of invalid absenteeism at secondary level must not exceed three times the amount of weekly instruction per course. In Romania and Poland, if the number of absences of students is more than $50 \%$ of the total number of courses, a grade repetition might be required (Eurydice, 2011).

One of the methods of preventing the absence of legal regulation is the family sanctions. In some states of the United States, the parents of students who are absent are obliged to cooperate with the school. Parents who do not attend the interviews that the teacher has determined are subject to fines (Gullatt ve LeMoine, 1997). Another practice related to absenteeism is the zero tolerance policy. In this practice, schools do not accept any excuse for their students other than their approved paper from health institutions. Low scores are given students who absent without a valid excuse. In some schools this practice is done for a maximum of 10 days, including a medical excuse (Bishop, 1989).

Another method that has been tried to prevent absences is that students have to come to school on weekdays and take remedial training based on the lesson hours they are absent. Students who cannot successfully complete remedial training will receive remedial training the following week. Students who are absent for 10 days are considered to be unsuccessful for that grade (Kube and Ratigan, 1992). In England, students who are absent without excuses are given fines. The monetary penalty can be given by the police, the local forces or the school head (BBC News, 2015).

\subsection{In-school Practices}

One of the efforts to prevent absence is to provide in-school communication. Research shows that communication between teacher and student has a significant effect on absenteeism (Testerman, 1996). It is important to provide continuous feedback to students who are absent and discuss the solution (Zhang, Katsiyannis, Barrett and Willson, 2007). In addition, it is considered that if the physical environment of the school meets the needs of the student, the loyalty of the student to the school will increase and this commitment will decrease the numbers of school absenteeism. Social activities at school also have important effects on absenteeism (Gömleksiz and Özdaş, 2013).

In research conducted by Hannover Research (2016), research-based strategies for attendance at secondary and high school levels has been researched. Three successful school districts have been dealt with in this direction. The study also included exemplary incentives to be offered by teachers and school administrations. Table 1 presents some incentives that can be appropriate in the secondary setting (Hanover Research, 2016).

Table 1. Incentives Offered in Secondary Schools

\begin{tabular}{|c|c|}
\hline Teachers Can Offer & Administration Can Offer \\
\hline $\begin{array}{ll}\text { - } & \text { Positive comments to students } \\
\text { - } & \text { Positive phone calls or notes to parents } \\
\text { - } & \text { School homework pass } \\
\text { - } & \text { Certificates for the best record or most improved attendance } \\
& \text { record }\end{array}$ & 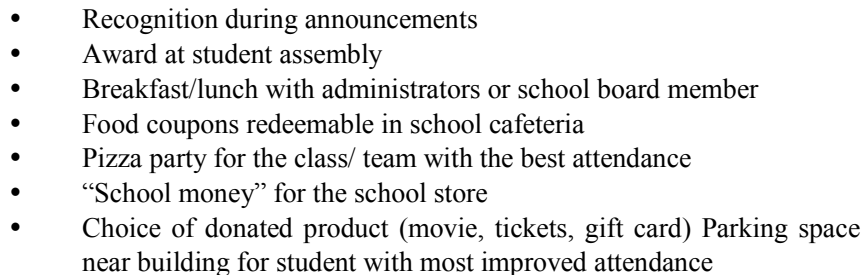 \\
\hline
\end{tabular}


Georgia middle school, which takes advantage of in-school strategies to avoid absence, detects attendance on a weekly, monthly and semester basis. Each class rewards classroom lessons with milk and buns, which is the best participation on a monthly basis. In the high school, there are difficulties for absent students. Seven unexcused absences mean failure. However, students in high school has incentives. Students who have fewer two absences can earn extra 10 points in their final exams (Hanover Research, 2016).

A documentary published by the Government of Wales has included suggestions and practices on attendance of the students. In an exemplary application (participation tree project), gold was given to students who continued $100 \%$, silver to students who continued $98 \%$, and bronze leaves to students who continued $95 \%$. At the end of each semester, each student wins his or her leaf and is rewarded with a certificate by the school council, which leads to $95 \%$ attendance (Welsh Government, 2011).

Another documentary issued by the Queensland Government of Australia provides a concrete applications to promote attendance. Attendance thresholds and targets for individual students were set at some schools visited (Queensland Government Department of Education, Training and Employment, 2012). These are set out in Table 2.

A report on absenteeism issued by the New Scotland, Canada Education and Early Childhood Development Department also mentions that some schools provide incentives to improve attendance, including student recognition, classroom awards and exemption from exams when grades and attendance are high (Nova Scotia Education and Early Childhood Development, 2016)

A report on absenteeism issued by the Los Angeles Education Department has emphasized the various activities to reduce absenteeism. The reward system for participation is also mentioned in this context. It has been emphasized that each school should have a system to award participation. At primary school level, students are recognized in the parliaments and assistant principals, counselors and teachers are individually awarded and congratulated students at the high school level where the certificates are issued. It also provides rewards for excellent participation by announcing for every student on the school website (Los Angeles County Education Coordinating Council, 2012).

\subsection{Computer Technology}

The first step in controlling absenteeism is to establish an effective monitoring and evaluation system. This system, which will be created with the aid of a computer, will be able to intervene immediately and develop solutions for absenteeism (Shute and Cooper, 2015). Another important technological development to avoid absenteeism is seen as mobile phones. Thanks to the mobile phone, information about absenteeism can be communicated to the parents instantly and the attendance of the student can be ensured.

In 2007, the Ministry of National Education established e-School System and e-School Parent Information System. Prior to 2007, there was no centralized absence of attendance. Schools have kept absenteeism records by recording them in a notebook. If centralized data were needed, data was collected from the schools by official letter. With the passing of the e-School System in 2007, absenteeism started to be monitored with a central monitoring and evaluation system.

The E-School Parent Information System gives parents and students the opportunity to access information on absenteeism. Parents or students can enter the system with their own personal information and control their knowledge. In addition, a text message is sent to the parents via 8383 short message service which is established as an integrated e-School System. The parent can be informed on the same day that the student is absent. According to the Regulation on the Secondary Education Institutions of the Ministry of National Education, it is obligatory to inform parents about absenteeism by post in certain periods, on the 5th, 15th and 25th days of the absence (MoNE, 2013).

With the "No Child Left Behind" project started in 2001 in America, all education regions regularly keep the data on absenteeism and send them to regional agencies. This is expected to lead to joint steps to combat absenteeism in the states and the states (Promote Prevent, 2012).

Table 2. Attendance thresholds and targets in schools

\begin{tabular}{|c|c|c|}
\hline School & Threshold / Target & Action \\
\hline Cairns West State School & Over $95 \%$ attendance & Student rewarded in assembly \\
\hline \multirow{3}{*}{ Mabel Park State School } & $100 \%$ attendance & $\begin{array}{l}\text { Student receives a letter home (at the end of term) and an invitation } \\
\text { to a celebration morning tea }\end{array}$ \\
\hline & $\begin{array}{l}\text { Between } 75 \% \text { and } \\
90 \% \text { attendance }\end{array}$ & Teacher to follow up reason for absence. \\
\hline & Under $75 \%$ attendance & Student referred to welfare officer \\
\hline \multirow{3}{*}{ Mabel Park State High School } & Over $95 \%$ attendance & $\begin{array}{c}\text { Student receives 'positive attendance' letter and may access extra } \\
\text { privilege reward activities }\end{array}$ \\
\hline & Between $80 \%$ and $90 \%$ attendance & Continue to monitor student's attendance \\
\hline & Under $80 \%$ attendance & $\begin{array}{c}\text { Deputy Principal to investigate and refer student for case } \\
\text { management where needed }\end{array}$ \\
\hline
\end{tabular}




\subsection{Family Support}

The family is known to have a significant effect on student absenteeism. In this context, it has been observed that if the parents communicate well with their children and deal with their problems, the absenteeismm of the students decreases (Pehlivan, 2006). The basic role of parents in the struggle with absenteeism is to provide a good family environment and family communication for their children. Research conducted in general assigns importance to the education of parents' children in all social levels (Levin, Belfield, Muennig and Rouse, 2007).

Communication between school and family has an important for fight against absenteeism. Families with poor communication with the school have no influence on the absences of their children and do not take responsibility for it. The method that can be applied in this regard may be to implement compulsory family education to improve school-family communication. Parents who are students with a high degree of absenteeism may be forced to take part in the school trainings to ensure that their parents take responsibility for absenteeism (Reid, 2010).

Cairns West State School in Queensland has implemented the Academic Success Guarantee program to improve student participation. The program involves a service agreement between the school and parents. The school provides a commitment to work with students to reach academic benchmarks in a 'whatever it takes' culture for students who attend at least 95 per cent of the time. The agreement is signed between the school and interested parents. The key messages the program seeks to communicate are (Queensland Government Department of Education, Training and Employment, 2012).

- for parents: If you want your child to be successful, send them to school.

- for teaching staff (teachers and teacher aides): If kids come to school then we must do whatever it takes to ensure success.

- for administration staff: Supporting teachers, parents and kids by doing whatever it takes to ensure success.

The City Attorney's Truancy Prevention Program has educated over 250,000 families about the importance of attending school. The program's letters have directed over 70,000 families to general assemblies where families are taught the legal and practical consequences of truancy. Additionally, almost 4,000 families have been referred to City Attorney Hearings for one-on-one intervention. From these families, counselors have taken over 200 to SARBs and have referred 70 families for court intervention that includes diversion in lieu of prosecution (Los Angeles County Education Coordinating Council, 2012).

\section{Conclusion and Suggestions}

In this study, the effects of the strategies and methods of struggle against absenteeism in the compulsory education process are discussed. It is seen that the compulsory education of the countries mostly covers the period after the pre-school and before the higher education level. There has been some methos an most importants of them are legislative arrangements, in-school practices, computer technology and family-supported methods. In Turkey, more legal processes and computer-assisted intervention strategies are in the foreground. And also rewards and incentives has been emphasized. There is a need for more comprehensive and more cooperative policies to reduce absenteeism. Following the results of the survey, the following suggestions were made for the process in Turkey.

- Social activities (excursions, picnics, etc.) for students who regularly attend the school (eg 90\% attendance) can be arranged.

- Students who are regularly participating in the recruitment of the arrow can be awarded (eg, basketball on the spot, tickets for matches of volleyball teams).

- Various gifts (eg books, developer mind games) can be given to students who regularly participate in the school

- A student with a monthly number of days without absenteeism can be congratulated at the Flag Ceremony.

- Aletter of congratulation can be written to the parents and invited to the school due to regular absence.

- Cinema can be watched or allowed to perform sporting activities within the course hours to the classroom with the highest attendance rate in the school.

- Legal processes about absenteeism can be informed so that parents are informed about the possible consequences of absenteeism, like class repetition, reduced course success, reduced commitment to the school, etc. At the end of this process, a protocol document between the school and the parent can be signed.

- The development of physical and social facilities (such as sports halls, libraries, cafeterias, school halls, etc.) in the school can be improved so that students can have more time in school.

- School administration can develop business associations by engaging in stronger communication with families to prevent absenteeism.

\section{REFERENCES}

[1] Ahmad, F. Z. and Miller, T. (2015). The High Cost of Truancy. Retrieved from https://cdn.americanprogress.org/wp-content/uploads/2015/07 /29113012/Truancy-report4.pdf 02.06.2017

[2] Akçabay, F. C. (2012). Toplumsal değişim ve hukuk ilişkisi çerçevesinde zorunlu eğitim [Compulsory education in the 
perspective of the relationship between social change and law] (Unpublished doctoral thesis). Marmara University, İstanbul.

[3] Altınkurt, Y. (2008). Öğrenci devamsızlıklarının nedenleri ve devamsızlığın akademik başarıya olan etkisi [The Reasons For Students Irregular Attendance And The Effect On This Students Irregular Attendance On Their Academic Achievement]. Dumlupinar Üniversitesi Sosyal Bilimler Dergisi, 20, 129-142.

[4] BBC News. (2015). Derby truancy figures among worst in England. Retrieved from

http://www.bbc.com/news/uk-england-derbyshire-33046232 11.05 .2017

[5] Bishop, H. L. (1989). Put Teeth, Not Fangs, in School Attendance Policies. American School Board Journal, 176(2), 38.

[6] Büyüköztürk, Ş., Kılıç- Çakmak, E., Erkan-Akgün, Ö., Karadeniz, Ş. and Demirel, F. (2013). Bilimsel araştırma yöntemleri [Scientific Research Methods] (15. Bask1). Ankara: Pegem A.

[7] Creswell, J. W. (2014). Araştırma deseni-Nitel, nicel ve karma yöntem yaklaşımlarl [Research Design: Qualitative, Quantitative, and Mixed Methods]. (S. B. Demir, Çev. Edt.). Ankara: Eğiten Kitap Yayınları.

[8] Education Reform Initiative. (2015). Ilköğretimde öğrenci devamsizliğinin azaltilmasi politika analizi ve öneriler [Policy analysis and recommendations for reducing student unemployment in primary education]. Retrieved from $\mathrm{http} / /$ www.egitimreformugirisimi.org/wp-content/uploads/20 17/03/DevamPolitikaNotuTR.18.09.15.pdf 02.06.2017

[9] Eurydice. (2011). Avrupa'da zorunlu eğitim süresince sinıf tekrarl: Yönetmelikler ve istatistikler [Class repetition during compulsory education in Europe: Regulations and statistics]. Retrieved from

http://eacea.ec.europa.eu/education/eurydice/documents/them atic_reports/126TR.pdf 03.06.2017

[10] Eurydice. (2015). Compulsory Education in Europe, Facts and Figures. Retrieved from

[11] https://webgate.ec.europa.eu/fpfis/mwikis/eurydice/index.php /Publications:Compulsory_education_in_Europe_2014/15. 03.06.2017

[12] Gullatt, D. E. ve LeMoine, D. A. (1997). Assistance for the school administrator concerned about student truancy. Retrieved from http://files.eric.ed.gov/fulltext/ED409653.pdf. 03.06.2017

[13] Gömleksiz, M. N. and Özdaş, F. (2013). Öğrenci devamsızlıklarının eğitim denetmenlerinin görüşlerine göre değerlendirilmesi [An assessment of student (absenteeism) absence based on education supervisors' views]. Elektronik Sosyal Bilimler Dergisi, 12(47), 106-124.

[14] Hanover Research. (2016). Best practices for improving attendance in secondary schools. Retrieved from $\mathrm{http} / / /$ browardstudentservices.com/wp-content/uploads/2017/ 02/Best-Practices-for-Improving-Attendance-in-Secondary-S chools.pdf 15.05.2017

[15] Henry, K. L. (2007). Who's skipping school: Characteristics of truants in 8th and 10th grade. Journal of School Health, 77(1), 29-35.
[16] Kearney, C. A. (2008). School absenteeism and school refusal behavior in youth: a contemporary review. Clin Psychol Rev, 28(3), 451-471. doi: 10.1016/j.cpr.2007.07.012.

[17] Kube, B. A. and Ratigan, G. (1992). Does Your School Have a Clue?: Putting the Attendance Policy to the Test. The Clearing House, 65(6), 348-350.

[18] Levin, H., Belfield, C., Muennig, P. ve Rouse, C. (2007). The costs and benefits of an excellent education for all of America's children (Vol. 9): Teachers College, Columbia University New York.

[19] Los Angeles County Education Coordinating Council. (2012). A Comprehensive approach to improving student attendance in Los Angeles County. Retrieved from http://www.publiccounsel.org/tools/assets/files/Los-AngelesSchool-Attendance-Task-Force-Report_2-2-12.pdf. 22.05.2017

[20] MoNE. (2013). Ortaöğretim Kurumlar Yönetmeliği, T.C. Resmi Gazete [Republic of Turkey Official Gazette], 28758, 07.09.2013.

[21] MoNE. (2015a). Millî Ĕgitim Bakanlı̆̆ 2015-2019 Stratejik Planı [Ministry of National Education 2015-2019 Strategic Plan]. Retrieved from http://sgb.meb.gov.tr/meb_iys_dosyalar/2015_09/10052958 10.09.2015 sp 17.15imzasz.pdf 02.06.2017

[22] MoNE. (2015b). Okul Devamsızlığl ile Mücadele Risk Altındaki Çocuklar ve Ailelerine Yaklaşımlar Rehber Kitapçı̆̆l [Approaches to children and their families at risk for combating school failure guide booklet], İlköğretim Kurumlarına Devam Oranlarının Artırılması Projesi Yayını. Ankara.

[23] Nova Scotia Education and Early Childhood Development. (2016). Be There: Student attendance and achievement a discussion paper. Retrieved from https://www.ednet.ns.ca/docs/student-attendance.pdf. 10.05.2017

[24] Önder, E. (2017). Student Absenteeism in Secondary Education, Absenteeism-Related School Practices and Recommended Policies. Education and Science, 42(190). 361-378.

[25] Özbaş, M. (2010). İlköğretim okullarında öğrenci devamsızlığının nedenleri [The Reasons of Absenteeism in Primary Schools]. Education and Science, 35(156), 32-44.

[26] Öztekin, Ö. (2013). Lise Öğrencilerinin Devamsızlık Nedenlerinin İncelenmesi [An Examination Of The Reasons of High School Students' Absenteeism]. (Unpublished master thesis). Eskişehir Osmangazi University, Eskişehir.

[27] Pehlivan, Z. (2006). Resmi genel liselerde öğrenci devamsızlı̆̆ ve buna dönük okul yönetim politikaları (Ankara ili örneği) [The absenteeism at state secondary schools and related school management policies (Ankara Case)]. (Unpublished doctoral thesis), Ankara University, Ankara.

[28] Promote Prevent. (2012). Truancy Prevention Efforts in School-Community Partnerships. Retrieved from http://www.promoteprevent.org/sites/www.promoteprevent.o $\mathrm{rg} /$ files/resources/Truancy\%20Prevention\%20Efforts\%20in\% 20School_0.pdf. 05.06.2017

[29] Queensland Government Department of Education, Training and Employment. (2012). Improving student attendance. Retrieved from 
http://www.parliament.qld.gov.au/documents/tableOffice/Tab ledPapers/2012/5412T21.pdf. 20.04.2017

[30] Queensland Government Education Department, Training and Employment (2015). The five step approach. Retrieved from http://education.qld.gov.au/everydaycounts/schools/the-five-s tep-approach.html. 06.05.2017

[31] Reid, K. (2000). Tackling truancy in schools: a practical manual for primary and secondary schools. London; New York: Routledge.

[32] Reid, K. (2010). Finding strategic solutions to reduce truancy. Research in Education, 84(1), 1-18.

[33] Reid, K. (2014). Managing School Attendance: Successful intervention strategies for reducing truancy: Routledge.

[34] Rivers, B. (2010). Truancy: Causes, Effects, and Solutions. (Unpublished master thesis). St. John Fisher College, New York.

[35] Shute, J. W. ve Cooper, B. S. (2015). Understanding in-school truancy. Phi Delta Kappan, 96(6), 65-68.

[36] Smink, J., ve Reimer, M. S. (2005). Fifteen Effective Strategies for Improving Student Attendance and Truancy Prevention. National Dropout Prevention Center Network. Retrieved from http://files.eric.ed.gov/fulltext/ED485683.pdf. 12.04.2017.
[37] Stoll, P. (1990). Absent pupils who are officially present. Education Today, 40(3), 22-25.

[38] Teasley, M. L. (2004). Absenteeism and truancy: Risk, protection, and best practice implications for school social workers. Children \& Schools, 26(2), 117-128.

[39] Testerman, J. (1996). Holding at-risk students: The secret is one-on-one. Phi Delta Kappan, 77(5), 364.

[40] Vaverchak, J. and Harris, S., (2014). Improving student attendance. Retrieved from http://www.sde.ct.gov/sde/lib/sde/pdf/alliance_districts/conve ning/improving_student_attendance.pdf. 12.04.2017

[41] Victoria State Government Education and Training Department (2017). Strategies proven by schools to reduce student absence and lateness. Retrieved from http://www.education.vic.gov.au/Documents/about/programs/ health/reducestudentabsence.Docx. 14.05.2017

[42] Welsh Government (2011). Strategies for schools to improve attendance and manage lateness. Retrieved from http://dera.ioe.ac.uk/2945/3/110308section3en.pdf. 20.04.2017

[43] Zhang, D., Katsiyannis, A., Barrett, D. E. ve Willson, V. (2007). Truancy offenders in the juvenile justice system examinations of first and second referrals. Remedial and Special Education, 28(4), 244-256. 